\title{
Utilization of bio gas slurry and bio gas slurry enriched with goat's urine fermented on plant height, leaf production and chemical compositions on Indigofera zollingeriana
}

\author{
R Arif , N Ginting, I Sembiring \\ Animal Production Program, Faculty of Agriculture, Universitas Sumatera Utara, \\ Medan 20155 \\ E-mail: nurzainahginting@gmail.com
}

\begin{abstract}
The research objective was to examine the utilization of bio gas slurry and bio gas slurry enriched with goat's urine fermented on Indigofera zollingeriana. The experiment was conducted at the Goat Farm Research Station Sei Putih, Galang, North Sumatera, from March until August 2015 using 24 plants of Indigofera zollingeriana. Design experiment was used split plot design where main plots were different dosages of fertilizer, i.e. R1 (75), R2 (150) and R3 (225) $\mathrm{ml} / \mathrm{plot}$ with four replications. The sub plots were types of fertilizer, i.e. slurry (P1) and slurry and goat's urine fermented (P2). The research parameters were plant height, leaf production and chemical compositions (rough fat, NDF and ADF).

The results showed that dosage fertilizer application of gas slurry and bio gas slurry enriched with goat urine fermented was not significantly different to plant height, leaf production and crude lipid. There was no significantly different on plant height between types of fertilizer, i.e. bio gas slurry and bio gas slurry enriched with goat's urine fermented. There were significantly different $(\mathrm{P}<0,05)$ between types of fertilizer, i.e. bio gas slurry and bio gas slurry enriched with goat's urine fermented on leaf production and chemical compositions. It is conclude that utilization of bio gas slurry enriched with goat's urine fermented increase productivity of Indigofera zolingeriana.
\end{abstract}

\section{Introduction}

Indigofera zollingeriana is a leguminous plant, trees for animal fodder which gives better nutrients especially protein, phosphor, and Calcium (Tarigan and Ginting, 2011). The growth and Indigo's productivity reach it prime at rainy season, yet the growth rate lessen in severe drought stresses. Therefore, Indigo is categorized as a tolerant plant toward severe drought (Herdiawan, 2013). Indigofera is commonly used as cover crops in plantations area like coffee, as green fertilizer, dyeing cloth, and herbal medicine (Herdiawan and Krisnan, 2014).

Indigofera can be used as basal fed goats in replacement of grass. This thing benefits farmer especially in extreme climate followed by flood phenomenon cause farmer getting trouble to cut the grass. Indigofera has better growth ability and can be functionalized at once as a soil boundary.

The used rate of Indigo is 25-75\% from total fed dry ingredients (Sirrahinuruk and Sirait, 2009). Indigos research can be used by farmer these days, for helping a good animal growth needed cheap fed resources, easy to get and have nutrient content especially good protein. Animal such as milking goat, i.e. Peranakan Etawah needs such fed.

Biogas technology is one technology that is right to cultivate livestock waste. Livestock waste is very significant to produce greenhouse gases that lead to climate change. Indonesia is very susceptible with 
the climate change impact like flood and drought that leads agriculture land become parched, cultivating season happened and outbreak from OPT (Plant Pest Organisms). Therefore, the government launches Regional Action Plan (RAD) Greenhouse Gases and RAD GRK in North Sumatera decide a policy for doing livestock feces cultivation turned to gas bio as well as compost (Ginting, 2012).

Livestock feces which are in solid shapes that is feces or in liquid that is urine cultivated in a biogas digester (Ginting and Mustamu, 2012) produces biogas and another product that is called slurry. This biogas technology is designed with continue system in order to both biogas as well as slurry are produced every day. Slurry as such an organic fertilizer containing macro and micro elements that are needed by plant such as $\mathrm{N}, \mathrm{P}, \mathrm{K}, \mathrm{Mg}, \mathrm{Ca}, \mathrm{Cu}$, and $\mathrm{Zn}$. The content of nutrients in slurry can be said complete yet less amount. According toKonkaew at al. (2004) although the nutrients are little, yet the organic fertilizer can fix the physical and biological of the soils and the repair will be positive influential toward chemical soil characteristic. Because of the little content of nutrients so the organic fertilizer is need to enhance the quality with adding other substance for example goat urine, it contained nitrogen, phosphor and potassium better from goat's as example. Every goat can produce 2.5 liter of urine per day.

\section{Materials and Methods}

\section{Location and Time}

The research was done in Goat Research Centre, Sei Putih, Galang,North Sumatera. It took about six months since March until August 2015.

The used materials were Indigofera seed two months old, biogas slurry fertilizer and bio gas slurry which enriched with fermented goat urine (100 ml urine was added to $1000 \mathrm{ml}$ slurry).

The experiment was a split plot design with using two factors which were:

1. First factor that used as sub plot is fertilizer resource. P1: biogas slurry fertilizer

P2: biogas slurry fertilizer which enriched with fermented goat's urine.

2. Second factor that used as main plot is fertilization dosage.R1: fertilizer with doses 75 $\mathrm{ml} /$ plot ( 0.75 ton/ha) ; R2: fertilizer with doses $150 \mathrm{ml} /$ plot (1.5 ton/ha) ; R3: fertilizer with doses 225 $\mathrm{ml} / \mathrm{plot}(2.25 \mathrm{ton} / \mathrm{ha})$

This research had performed four repetitions so there were 12 treatment combinations on P1 and 12 treatment combinations on P2. Land preparation starts with making 24 plots with size of one to one meter. Each plot is given basic fertilizer which is $1 \mathrm{~kg}$ of solid compost per plot or $10 \mathrm{ton} / \mathrm{ha}$ then silenced for a week. Repetition in fertilizing is done every four weeks until week twenty-four.

Harvest/defoliation begins with trimming for all Indigofera was done on four-week after planting with the aim to homogenize growth by using a saw. Defoliation then performed within intervals of 60 days. For cutting height is one meter from the ground.

\section{Result and Discussion}

\section{Height of Indigofera zollingeriana}

The study resulted that Indigofera zollingeriana height by the treatment of given biogas slurry or given slurry which enriched with goat's urine fermented showed no significantly different on plant height which is an indicator of plant growth. There was no differences also on dose given factor. The results can be seen in Table 1 below. 
Table 1. Indigofera zollingeriana height $(\mathrm{cm})$

\begin{tabular}{|c|c|c|c|c|}
\hline \multirow{2}{*}{ Sub plots } & \multicolumn{3}{|c|}{ Main plots } & \multirow{2}{*}{ means } \\
\hline & $\mathrm{R} 1$ & $\mathrm{R} 2$ & R3 & \\
\hline $\mathrm{P} 1$ & 133.75 & 128 & 133.87 & $132.54 \pm 4.07^{\mathrm{a}}$ \\
\hline $\mathrm{P} 2$ & 124.31 & 123.37 & 130.56 & $126.08 \pm 3.90^{\mathrm{a}}$ \\
\hline means & $129.03 \pm 6.67^{\mathrm{a}}$ & $125.685 \pm 3.27$ & $133.21 \pm 3.75$ & \\
\hline
\end{tabular}

Directions: P1= Indigofera zollingeriana fertilized by slurry $\mathrm{P} 2=$ fertilized by slurry which enriched with fermented goat's urine

No difference in growth likely due to nutrients contents in both types of fertilizer on growing. Commonly organic fertilizer contain small amount of nutrients, for example chemical contents of slurry such as NPK are $0.25,0.13$ dan $0.12 \%$ respectively while $\mathrm{N}$ content in urine is $0.51-0.71 \%$. N is supporting nutrients for plant growth.

\section{Leaf Production}

The production of Indigofera zollingeriana leaf ( fresh) was presented in Tabel 2. The highest production of fresh ingredients of leafs was obtained through fertilizing with slurry which enriched with fermented goat urine $(\mathrm{P}<0,05)$.

Table 2. Leaf production of Indigofera zollingeriana $(g)$

\begin{tabular}{|c|c|c|c|c|}
\hline \multirow{2}{*}{ Sub Plots } & \multicolumn{3}{|c|}{ Main plots } & \multirow{2}{*}{ Means } \\
\hline & $\mathrm{R} 1$ & $\mathrm{R} 2$ & $\mathrm{R} 3$ & \\
\hline $\mathrm{P} 1$ & 290.625 & 225.875 & 306 & $274.167 \pm 42.52$ \\
\hline $\mathrm{P} 2$ & 424.875 & 276.376 & 489.250 & $396.833 \pm 109.17^{\mathrm{a}}$ \\
\hline Means & $357.75 \pm 94.92^{\mathrm{a}}$ & $251.126 \pm 35.70^{\mathrm{a}}$ & $397.63 \pm 129.57^{\mathrm{a}}$ & \\
\hline
\end{tabular}

Directions:P1= Indigofera zollingeriana fertilized by slurry P2 = fertilized by slurry which enriched with fermented goat's urine, different superscripts in the same row or column showed a noticeable difference to the Duncan test $(\mathrm{P}<0.05)$

This may be related to the intensity of defoliation. Crop production on dry season can still be improved if implemented by defoliation, where the research conducted by Herdiawan and Sutedi (2012), 60 days of defoliation can stimulate the growth of branching. Defoliation is done with a range of 60 days and effectively stimulates the growth of branches and also leaf production. Table 2 showed that leaf production on treatment with slurry which enriched with fermented goat's urine was significantly different $(\mathrm{P}<0.05)$ than slurry alone. Increase of branching accompanied by the emergence of leaf though the leaf production was not optimal. In normal climatic conditions, it is expected that leaf production will be better. This relates to the content of nutrients which contained on treatment with slurry which enriched with fermented goat's urine. It will facilitate faster growth and with defoliation 60 days then branching got better also accompanied by maximum leaf accretion.

Application of giving Indigofera to goats like the one conducted in Sei Putih Goat Research Centre is to drape rod pieces of Indigofera on cage. The next day, seen some part of the leaves were gone but still left a lot of steam. This means that the goat choose to eat leaves rather than the steam. Slurry which enriched with fermented goat's urine application on this study in fact has the ability to increase the leaf production better than any other treatment. It means, to meet the needs of the goat for 
Indigofera, it is better to conduct fertilization using slurry which enriched with fermented goat's urine. The more the number of leaf than steam means the legume has good quality as forage.

By Suharlina and Abdullah (2012) said that a dose of liquid organic fertilizers affect the $\mathrm{N}$ content of the soil at a time causing more soil contained the $\mathrm{N}$ elements for plants. Organic fertilization with addition of urine has its own work way because it's containing growth hormone. As it is improving the chemical, physical, and biological soil, it is also trigger leaf and stem production.

The use of slurry as fertilizer relatively requires little expense given the slurry is a by product of biogas technology where the main result of biogas which is an alternative energy. Ginting (2014) found that the installation of biogas unit with plastic raw material obtained $\mathrm{B} / \mathrm{C}$ is 2.56 big while the ROI for the first year is: $85 \%$. This means biogas technology is very profitable and produce many slurry so even though the slurry used excessively, it will not be detrimental to farmers and will cause element nutrients storage in the soil. Utilization of slurry which enriched with fermented goat's urine also cost little expense, considering goat urine is available every day especially in people who raise goats. Besides, Ginting (2015) stated that utilization of slurry was balanced between goat feces and bagasse which applied to mix pasture at dose $600 \mathrm{ml} / \mathrm{plot}$ is very profitable. From the production of fresh pasture mixture were obtained Digitaria milanjiana and Clitoria ternatea are 487,50 g/plot/harvest or 170,6 ton/ha/year.

According to Rauf (2013) fertilization doses with organic fertilizer for every hectare of land is between 10 to 20 tons, while in this study the highest fertilization doses is $225 \mathrm{ml}$ is equivalent to 2.25 tons per ha although the first soil process have been given basic fertilizer/manure 10 tons/ha. Purbajanti (2010) stated that the application of fertilizer 20 tons per ha increase forage production and dry ingredients of Bengal grass (Panicum maximum) plant than without fertilizer.

Ginting (2015) said that the use of slurry as a liquid fertilizer will increase crop production. Liquid organic fertilizer can stimulate the growth of higher plants to produce high crop fresh ingredients. The content of nutrients contained in a liquid organic fertilizer appears to participate spur the growth of soil microorganisms. Organic fertilizer on a regular basis will eventually form the reserves of nutrients in the soil. In the long term the effect of this fertilizer can still give good results.

Vergnoux et al. (2009) said that in the countries in Europe that produces cheese, liquid waste from cheese manufacturing industry that resembles the slurry used to remediate soil. Organic fertilizer produced from cattle dung can be used to restore degraded land structure, fertilize back farmland, and as a medium for the plants as well as reducing dependence on the use of chemical fertilizers.

\section{Chemical Compositions}

Chemical compositions in this research were presented in Table 3. Data content of rough fat, NDF and ADF showed that slurry fertilization enriched with fermented goat urine compared with slurry fertilization alone caused better content of rough fat, NDF and ADF.

Table 3. Content of Rough Fat, NDF, and ADF Indigofera zollingeriana through Fertilization with Slurry and Slurry Enriched with Fermented Goat's Urine

\begin{tabular}{|c|c|c|c|}
\hline Slurry Fertilization & Rough Fat & NDF (\%) & ADF (\%) \\
\hline R1 & 2.81 & 33,5947 & 23,3705 \\
\hline R2 & 2.96 & 32,7616 & 22,3278 \\
\hline R3 & 3.08 & 35,645 & 24,9680 \\
\hline \multicolumn{4}{|c|}{ Slurry Fertilization Enriched with Fermented Urine } \\
\hline R1 & 2.87 & 34,2751 & 25,1272 \\
\hline R2 & 3.04 & 31,1472 & 21,8093 \\
\hline R3 & 3.22 & 32,8382 & 21,7989 \\
\hline
\end{tabular}


Chemical composition in I. zollingeriana was researched by Juniar et.al (2012) and they found that NDF and ADF worsen; i.e.54.24\% and $44.69 \%$ respectively. Possibly, these because Juniar et.al (2012) cultivated Indigofera at older age, i.e. nine months compare to this research, i.e. seven months. By Purbajanti (2012) said that increasing $\mathrm{N}$ which supplied by the ground, will enhance the growth of leaves and stems of plants and to increase dry matter also means improved forage results. Dry matter is a reflection from the content of protein on the plant. The protein content of plants is influenced by the type of plant, plant part, the growth stage, soil fertility, climate, temperature, light intensity and water stress.

Soil fertility is more influential where it is related to the nutrient content of the higher applied fertilizer. The content of NDF and ADF on treatment with slurry enriched with fermented goat urine indicates the Indigo plant has the ability to be better digested by livestock due to NDF and ADF are a reflection of plant fibers. NDF is a reflection of cell wall components including cellulose, hemicellulose, lignin and protein where the better quality of fertilizing, the NDF will go down. ADF is a reflection of hemicellulose components, cellulose and lignin, which is abundant in the cell wall. This section has a low digestibility, but not a problem for ruminant fed for the ruminant digestive tract contained rumen microorganisms. NDF and ADF are affected by several factors such as soil and climatic conditions, growth stage, genotype, sampling technique and the content of toxic in plants. Growth stage in this research has more influence on the content of NDF and ADF. Rough fat is essentially for improving goat milk quality. There is a tendency that by using slurry enriched with goat urine fermented improved rough fat content.

\section{Conclusions}

Application of slurry fertilizer enriched with fermented goat's urine at dose $225 \mathrm{ml} / \mathrm{plot}$ resulted leaf production increased significantly $(\mathrm{P}<0,05)$ compared with application of slurry although plant growth was not significantly different between types of fertilizer. The application also produces of better rough fat, NDF and ADF. As using slurry is relatively requires little expense given the slurry is a by product as well as urine therefore by using slurry or slurry enriched with goat urine fermented is recommended to animal stockers.

\section{References:}

[1] Ginting, Nurzainah and Novilda, E. Mustamu. 2012. The Application of biogas slurry as Organic Fertilizer on the Growth of Spinach Plant (Amaranthus tricolor). Proceedings. ISSN: 2089-208X. The $2^{\text {nd }}$ Annual International Conference Inconjunction with The 8th IMT-GT Uninet Biosciences Conferences. Syiah Kuala University. Indonesia.

[2] Ginting, Nurzainah. 2012. Supporting Policy to succeed the Regional Action Plan (RAD) Greenhouse Gas (GHG) emissions in North Sumatra. Innovation: Journal of Politics and Policy. Vol. 9 No. 1, March 2012. ISSN 1829-807.

[3] Ginting, Nurzainah. 2014. Economic Analysis with Applications Bio digester input Rotten Oranges (Citrus Nobilismicrocarpavar) for Fruit Flies (Drosophila melanogaster) in Karo. Proceedings: Research Seminar Lecturer-Student Faculty of Agriculture USU. USU Press, Medan. ISBN: 9794587699

[4] Ginting, Nurzainah. 2015. Economic Analysis Slurry Gas Utilization Bio Balance Dirt Ram and sugarcane dregs on Productivity Pasture Mixture. Proceedings of the National Scientific Seminar, 2015.Mechanical Industrial Engineering Department, Faculty of Engineering, University of North Sumatra, Medan. ISBN 7760197860272

[5] Herdiawan, I. 2013. Plant Growth Forage Legume Trees Indigofera zollingeriana At Various Extent Drought Stress Treatment. Journal of Animal Science and Veterinary Vol 18 \# 4 p. 258-264. ISSN 0853-7380

[6] Herdiawan, Iwan and Krisnan R. 2014.Productivity and Utilization Plant Leguminous Trees Indigofera zollingeriana on Dry Land.Wartazoa Vol. 24 No. 2 Th. 2014 Page.75-82. 
[7] Juniar Sirait, KistonSimanihuruk, RijantoHutasoit. 2012. Potential Indigofera sp. As Fed Goats: Products, Nutrition values and palatability. Pastura Vol. 1 No. 2: 56-60. ISSN: 2088 - 818X

[8] Kongkaew Kotchakorn, Annop Kanajareonpong and Thanuchai Kongkaew. 2004. Using of slurry and sludge from biogas digestion pool as bio-fertilizer. The Joint International Conference on "Sustainable Energy and Environment (SEE). Chiang Mai University, Chiang Mai, Thailand.

[9] Purbajanti, EndangDwi. 2010. Textbook of Soil Science and Fertility. Diponegoro University. Semarang.

[10] Purbajanti, EndangDwi. 2013. Grasses and Legumes. Graha Science. Semarang.

[11] Rauf, Abdul. 2013. Introduction to Soil Science. USU Press. Medan

[12] Simanihuruk, K and J. Sirait. 2009. Utilization of Leguminous Trees Indigofera sp. As Basal Fed Goats Boerka Growth Phase.National Seminar on Animal Husbandry and Veterinary Technology.Goat Research Centre, PO Box 1, 20585 Galang Sei Putih, North Sumatra.

[13] Sinaga, Fenris, Simon Ginting and Nurzainah Ginting. 2016. Growth Through Fertilization Indogofera zollingeriana by Biogas sludge enriched with fermented goat urine on Production of Fresh, Dry and Carrying Capacities in Prosiding Seminar Nasional Dies Ke-59 FakultasPertanian, Universitas Sumatera Utara. USU Press 2016. ISBN 9794588571

[14] Suharlina and Luki Abdullah. 2012. Increased Productivity Indigofera sp. For High Quality Forage Fed through Liquid Organic Fertilizer Application: 1. Forage Production and Its Impact on Soil Condition. Pastura Vol. 1 No. 2: 39-43

[15] Tarigan, A. and S.P. Ginting, 2011. Effect of Giving Extent Indigofera sp. Against Consumption and Fed Digestibility and Added Weight of Life Goat. Journal of Animal Science and Veterinary Vol 16 No. 1: 25-32. ISSN 0853-7380

[16] Vergnoux, A., M., Guiliano, Y. Le Dreau, J. Kister, N. Dupuy and P. Doumenq. 2009. Monitoring of the evolution of an industrial compost and compost prediction of some properties by NIR spectroscopy. Sci Total Environ (2009), doi: 10.1016 / j.scitotenv.2008.12.033 